\title{
Beyond the European Convention: Human Rights and the Common Law
}

\author{
Mark Elliott ${ }^{*}$
}

\begin{abstract}
Since its entry into force in 2000, the Human Rights Act 1998 has become largely synonymous with human-rights adjudication in the UK. In particular, the notion of common-law constitutional rights was largely eclipsed by the new legislation. However, in recent years, against the background of political uncertainty concerning the future of the Act, the UK Supreme Court has begun to place renewed emphasis upon the common law as a source of fundamental rights and values. In the light of those phenomena, this article examines the potential of the common law as a vehicle for the enforcement of human rights. In particular, it compares the capacity of the common law with that of the Act by reference to three vectors by reference to which the nature of a judicial system of human-rights protection may be characterised. The three vectors respectively concern the normative reach of the system, the rigour with which it equips courts to uphold rights, and the degree of constitutional resilience that rights exhibit in the face of adverse legislative or administrative action. It is argued that these three aspects of human-rights adjudication sit in relationship with one another, and that it is only by considering the ways in which they interact that the nature and extent of the common law's potential can be fully calibrated and assessed.
\end{abstract}

Public lawyers in the United Kingdom are used to living through interesting times. Indeed, ever since the big-bang reforms of the first Blair government in the late 1990s, the British constitution - in a way that perhaps only an unwritten, unentrenched, easy-to-amend constitution like the UK's can has found itself in an almost-constant state of change. Today, the outcome of the 2014 Scottish independence referendum is a particularly obvious engine of ongoing constitutional reform, the trend — or, as perhaps more accurately describes the British way, drift - towards a more-federalized model being increasingly hard to dispute. ${ }^{1}$ The prospect of radical constitutional reform is not, however, confined to internal institutional redesign in a post-devolution era. The UK's external relationships are also on the table in a way and to an extent that they have not been for several decades. This is most clearly evident in relation to membership of the European Union (EU), the wisdom of an in-out referendum having been a major issue in the 2015 general-election campaign. Meanwhile, repeal of the Human Rights Act 1998 (HRA) and the enactment of a 'British Bill of Rights' was proposed by the Conservative Party in its 2015 manifesto. ${ }^{2}$ Indeed, in a paper published in 2014 the Party went further still, advocating reforms that were acknowledged to be capable of triggering the UK's withdrawal from

\footnotetext{
* Reader in Public Law, University of Cambridge; Fellow, St Catharine's College, Cambridge. I am grateful to Trevor Allan, John Bell, David Dyzenhaus, David Feldman, Veronika Fikfak, Carol Harlow, Hayley Hooper, Kirsty Hughes, Dawn Oliver, Jason Varuhas and Jack Williams for their comments on an earlier draft of this paper. I am grateful too to those who attended my CLP lecture for their helpful questions and observations. The usual disclaimer applies.

${ }^{1}$ Cheryl Saunders, 'Devolution. Federation. Constitution. From here to where?', Sir David Williams Lecture, University of Cambridge, February 2015.

${ }^{2}$ Conservative Party, Strong Leadership, A Clearer Plan, A Brighter, More Secure Future (2015) 60, 73.
} 
the European Convention on Human Rights (ECHR) on account of their incompatibility with Britain's obligations under that treaty. ${ }^{3}$

Although such radical changes remain unlikely - if not, any longer, unthinkable - engaging in the constitutional futurology invited by these possibilities is both useful and valuable. This article therefore evaluates the state of domestic human-rights law by way of comparing it with the forms and degrees of protection of human rights that are presently available thanks to the presence on the statute book of the HRA and the UK's being a party to the ECHR. More particularly, the article considers the extent to which the doctrine of common-law constitutional rights is, or has the demonstrable potential to develop into, a substitute for the existing system of rights protection rooted in the HRA and the ECHR.

This analysis serves two useful purposes. First, it enables us to understand what (this aspect of) our domestic constitutional order looks like, so as (for instance) to be able better to appreciate the nature of its relationship with relevant European influences for as long as the latter persist. Second, considering elements of the constitution that are inherent - rather than, to some extent, grafted on by operation of potentially transitory statutory or external influences - serves to identify the terrain upon which any debate about further constitutional reform must take place. It is, for example, likely that even if a scorched-earth policy were pursued by means of HRA-repeal and ECHR-withdrawal, this would be followed by some form of domestic bill of rights. Yet the extent to which the framers of such legislation would have the luxury of painting upon a blank canvas necessarily turns, to some degree at least, upon the nature and extent of the common law's innate commitment to rights.

In order to realize the objectives sketched above, the article will examine and compare common-law and HRA-ECHR rights protection with respect to three vectors by reference to which the nature and potency of a juridical human-rights regime can be plotted. The first such vector concerns the normative reach of common-law and HRA-ECHR rights. Are the two bodies of rights co-extensive, or is the former but a pale shadow of the latter? The second vector relates to the protective rigour evidenced at common law and under the HRA-ECHR scheme respectively. Even if it were the case that the common law acknowledged all - or most or some - of the rights enshrined in the Convention, would courts upholding exclusively common-law rights have at their disposal adequate protective instruments? The third vector concerns the notion of constitutional resilience. Convention rights by virtue of their binding effect upon the UK in international law - are invested with a particular form of legal bite. As a result, the constitutional capacity of Parliament to reverse interpretations rendered under section 3 of the HRA and to ignore declarations issued under section 4 is marginalized if not rendered largely notional. However, as domestic constructs, common-law rights inevitably lack the international-law purchase that Convention rights have, raising questions about the extent, if any, to which they might be considered resilient in the face of adverse legislation.

\footnotetext{
${ }^{3}$ Conservative Party, Protection Rights in the UK (2014). This is not, however, the first time that the UK's involvement in the ECHR has been fundamentally reconsidered at the highest political levels: see Ed Bates, 'British Sovereignty and the European Court of Human Rights' (2012) 128 LQR 382; Ed Bates, 'The UK and European Human Rights: A Strained Relationship - The Long View' in Katja Ziegler, Elizabeth Wicks and Loveday Hodson (eds), The UK and European Human Rights: A Strained Relationship? (Hart 2015).
} 
It will be argued that the three vectors sit in relationship with one another, and that it is by understanding the nature of the interactions between them that we can come to appreciate the potential of common-law rights. In particular, while there may exist a normative core of such rights that are singled out for particular recognition, the common law's commitment to rights diminishes as we shift from the core to the normative penumbra. That commitment is evidenced by the protective lengths to which the common law is prepared to go in relation to particular rights, such lengths being notably greater in relation to rights lying at or close to the normative core. In turn, such protective endeavours inform the extent of a given right's constitutional resilience, certain (core) rights being especially resistant to legislative or administrative infraction.

It will be contended that, analysed thus, the common law constitutes a potentially potent vehicle for the enforcement of fundamental rights, but that it is essential that points of distinction - as well as points of commonality - between the HRA-ECHR and common-law regimes be acknowledged. Two extreme analyses must therefore be resisted. It would be unrealistic to argue that domestic law in this area is so extensive, rigorous and resilient as to render the HRA-ECHR essentially redundant, such that (for instance) repeal of the former and withdrawal from the latter are prospects that can be met with utter equanimity. However, it would be equally mistaken to suppose that the common-law and HRAECHR regimes are so radically different that the absence of the former would transform judicial protection of human rights in the UK beyond all recognition. The true position, it will be argued, is more subtle and more complex than either of these bald analyses allows.

\section{Normative Reach}

\section{The Idea of Common-Law Rights}

In the years leading up to the enactment and activation of the HRA, the notion of common-law 'constitutional' or 'fundamental' rights acquired a certain prominence. Particular attention was paid to the right of access to court, ${ }^{4}$ which was held to encompass a right of access to confidential legal advice, ${ }^{5}$ and the right to freedom of expression. ${ }^{6}$ Inevitably, no authoritative catalogue of such rights exists, although it is hard to dispute the proposition that such rights as could be inferred from the case law appeared to occupy a terrain substantially narrower than that occupied by the Convention rights. Indeed, it was the failure of domestic law to protect the full range of such rights that underpinned the desire of the Blair administration to legislate so as to see 'rights brought home'. ${ }^{7}$ The paradoxical implication was that while Convention rights were somehow immanent within domestic law, legislative domestication was nevertheless required. That paradox is echoed by the juxtaposition of rhetorical claims about the capacity of the common law - Lord Donaldson MR's assertion that 'you have to look long and hard before you can detect any difference between the English common law and the principles set out in the Convention, ${ }^{8}$ being perhaps the best example - with the practical

\footnotetext{
${ }^{4}$ Eg Raymond v Honey [1983] 1 AC 1 (HL); R v Lord Chancellor, ex parte Witham [1998] QB 575 (QBD).

${ }^{5}$ Eg $R$ v Secretary of State for the Home Department, ex parte Leech (No 2) [1994] QB 198 (CA).

${ }^{6} \mathrm{Eg} R v$ Secretary of State for the Home Department, ex parte Simms [2000] 2 AC 115 (HL).

${ }^{7}$ Rights Brought Home: The Human Rights Bill (White Paper, Cm 3782, 1997).

${ }^{8} R v$ Secretary of State for the Home Department, ex parte Brind [1991] 1 AC 696, 717 (HL).
} 
reality of domestic courts' unpreparedness in many cases $^{9}$ to confer upon fundamental rights a degree of protection the equivalent of that available in Strasbourg.

This apparent paradox is resolvable to some extent by reference to a distinction that can - and needs to - be drawn between values associated with the common law and rights protected by it. It is true that the Convention embodies rights that amount to specific manifestations of values that, at some level of abstraction, are reflected in the English common-law tradition. However, it does not follow from this that the common law did, or does, contain a catalogue of rights that equates to the body of rights found in the Convention. To possess a legal right arguably implies some form of enforceability - and, in the public-law realm, some degree of ring-fencing against the prospect of legislative or administrative incursion. It was in these senses that the common law sometimes fell short. For all that 'rights' might have been acknowledged at common law, practical enforcement was limited on occasion, as decisions like Brind ${ }^{10}$ and Smith ${ }^{11}$ show. Although in both cases it was acknowledged that human rights were at stake, the courts' capacity to protect the relevant rights was limited by broad adherence to the conventional doctrinal machinery of domestic administrative law. In particular, the retention in such cases of Wednesbury unreasonableness - even in its adapted, 'sub-Wednesbury' guise $^{12}$ - as the operative ground of review places in some doubt the extent to which they can properly be characterized as cases evidencing the protection of 'rights' as such, as distinct from cases decided in accordance with orthodox administrative-law doctrine albeit informed by the fact that relevant values were engaged.

For these reasons, it is important to approach claims about common-law constitutional rights with some caution. It is far from clear that the normative range of the human-rights values immanent within the common law is co-extensive with the rights set out in the Convention, while those values that were acknowledged were not inevitably translated through the use of practical adjudicative tools into meaningfully enforceable rights. This is not to suggest that no viable claim can be made to the effect that, prior to the HRA, common-law rights - properly so called - existed. Rather, the point is that such claims must be appropriately qualified if revisionism is to be avoided. There were certainly cases in which the courts gave glimpses of the common law's potential: cases in which some degree of ring-fencing was secured by means of interpretive methodology and more-rigorous oversight supplied by the adoption of a form of review that went beyond Wednesbury. ${ }^{13}$ It would, however, stretch credibility beyond breaking point to suggest that in the pre-HRA common law we find a set of domestic-legal human rights that rendered the enactment of the HRA otiose. And so, for 'bringing rights home', read 'giving domestic legal effect to rights that correspond to some extent with values acknowledged at common law' - a less catchy slogan, but a more accurate one.

\footnotetext{
${ }^{9}$ Such as $R$ v Ministry of Defence, ex parte Smith [1996] QB 517 (CA).

${ }^{10}$ ibid.

${ }^{11}$ Smith (n 9).

${ }^{12}$ See generally Sir John Laws, 'Wednesbury' in Christopher Forsyth and Ivan Hare (eds), The Golden Metwand and the Crooked Cord (Oxford: Clarendon Press, 1998).

${ }^{13}$ Such cases are discussed below.
} 


\section{The Advent of the Human Rights Act}

Once the HRA entered onto the scene, common-law rights quickly found themselves in its shadow. And while this development is intuitively unsurprising, it is worth pausing to consider what might lie behind it. Two possibilities arise. The first turns upon a characterization of common-law rights as little more than an anticipatory facsimile of certain Convention rights - placeholders embraced by the courts pending incorporation of the Convention. On this view, which Lord Rodger appeared to endorse in Watkins, ${ }^{14}$ common-law rights could, and perhaps even should, be permitted to fall by the wayside once the ECHR - the 'real deal', to use a term that Lord Rodger did not - was fully domestically accessible. As Lord Rodger put it, in developing the doctrine of common-law constitutional rights, the 'judges were, more or less explicitly, looking for a means of incorporation avant la lettre, of having the common law supply the benefits of incorporation without incorporation' ${ }^{15}$ Viewed thus, commonlaw rights amounted to little more than a device deployed in order to mitigate the effects of the prohibition identified in Brind upon 'back-door incorporation' ${ }^{16}$ For the reasons given above, the use of that device did not always bear fruit - but, in any event, as Lord Rodger went on to say in Watkins, 'heroic efforts' of the type evidenced by the judges who had developed the notion of common-law rights were rendered 'unnecessary' by the advent of the HRA. ${ }^{17}$

There is, however, a second way of seeking to understand (what appeared, for a time, to be) the eclipse of common-law by Convention rights. Whereas Lord Rodger's analysis effectively downplays the normative significance and longevity of common-law rights, by postulating that they were essentially makeshift constructs, an alternative narrative offers a subtly - but significantly - different account. On this second view, the overshadowing of common-law rights is a merely empirical, as opposed to a more profoundly normative, phenomenon. Claimants began to argue, and courts began to decide cases, on the basis of the rights scheduled to the HRA because they had become readily accessible and conveniently tabulated - not because common-law rights had been either displaced or exposed as mere portents of the Convention rights that were to come. Support for this version of the narrative can be found both in the early and in what might turn out to the late case-law of the HRA era.

An obvious example of the former is Daly. ${ }^{18}$ Lord Bingham's leading speech in that case turned almost entirely upon the common-law right to legal professional privilege, the fact that applying Article 8 ECHR would have yielded the same result being mentioned as little more than an afterthought. A clear implication of Lord Bingham's speech was that common-law and Convention rights would co-exist under the HRA. And what was implicit in Lord Bingham's speech was explicit in Lord Cooke's. He considered it to be 'of great importance ... that the common law by itself is being recognized as a sufficient source of the fundamental right of confidential communication with a legal adviser ${ }^{\prime 19}$ Lord

\footnotetext{
${ }^{14}$ Watkins v Secretary of State for the Home Department [2006] UKHL 17, [2006] 2 AC 395.

${ }^{15}$ ibid [64].

${ }^{16}$ Daly (n 8) 762 (Lord Ackner).

${ }^{17}$ Watkins (n 14) [64].

${ }^{18} R$ (Daly) v Secretary of State for the Home Department [2001] UKHL 26, [2001] 2 AC 532.

${ }^{19}$ ibid [30].
} 
Cooke went on to say that 'some rights are inherent and fundamental to democratic civilized society. Conventions, constitutions, bills of rights and the like respond by recognising rather than creating them ${ }^{20}{ }^{20}$ Of course, it is no coincidence that Daly concerned the right of confidential access to legal advice - a right that, as noted above, is regarded as an intimate component of the right of access to court, the latter being a right to which the common law has demonstrated a longstanding commitment. Daly is not therefore a basis for any grand claims about the equivalence in scope of common-law and Convention rights; it does, however, provide a strong antidote to claims that common-law rights were swept aside by the HRA.

Although, for some commentators, such a reading of Daly was subsequently placed in doubt by decisions such as Watkins - in which, according to Brice Dickson, 'the coffin lid on constitutional rights was well and truly screwed down' ${ }^{21}$ - the relevance of the common law in this area has since been boldly reasserted. In a series of judgments, including Osborn $v$ Parole Board, ${ }^{22}$ Kennedy $v$ Charity Commission, ${ }^{23} R$ (HS2 Action Alliance Ltd) $v$ Secretary of State for Transport, ${ }^{24} A v B B C^{25}$ and $R$ (Evans) $\checkmark$ Attorney-General ${ }^{26}$ the Supreme Court has placed renewed emphasis upon the common law as a source of fundamental constitutional values and rights. ${ }^{27}$ Against this background, Lady Hale has suggested that 'UK constitutionalism' is 'on the march', meaning that 'there is emerging a renewed emphasis on the common law and distinctively UK constitutional principles as a source of legal inspiration'. ${ }^{28}$

\section{Common-Law Resurgence}

To what, however, does this common-law resurgence actually amount? Three strands within it can usefully be distinguished. The first - and the most uncontroversial - concerns common-law resilience. It amounts to the modest proposition that common-law rights survive the HRA. As Lord Reed put it in Osborn, the Act 'does not ... supersede the protection of human rights under the common law or statute, or create a discrete body of law based upon the judgments of the European

\footnotetext{
${ }^{20}$ ibid [30].

${ }^{21}$ Brice Dickson, Human Rights and the United Kingdom Supreme Court (OUP 2013) 28.

22 [2013] UKSC 61, [2014] AC 1115.

${ }^{23}$ [2014] UKSC 20, [2014] 2 WLR 808.

${ }^{24}$ [2014] UKSC 3, [2014] 1 WLR 324.

${ }^{25}$ [2014] UKSC 25, [2014] 2 WLR 1243.

${ }^{26}$ [2015] UKSC 21.

${ }^{27}$ For discussion, see Roger Masterman and Se-shauna Wheatle, 'A Common Law Resurgence in Rights Protection?' [2015] EHRLR 57; Richard Clayton, 'The Empire Strikes Back' [2015] PL 3; Dinah Rose, What's the Point of the Human Rights Act? (Politeia 2015).

${ }^{28}$ Lady Hale, 'UK Constitutionalism on the March?' (Constitutional and Administrative Law Bar Association Conference, 12 Juyly 2014) <https://www.supremecourt.uk/docs/speech-140712.pdf> accessed 24 March 2015. See also Lord Neuberger, "Judge not, that ye be not judged": Judging judicial decision-making' (F A Mann Lecture, 29 January 2015) <https://www.supremecourt.uk/docs/speech-150129.pdf> accessed 24 March 2015.
} 
court' ${ }^{29}$ Such a view tells strongly against the view advanced by Lord Rodger that common-law rights were nothing more than a disposable constructs fashioned to secure incorporation without incorporation', ${ }^{30}$ but to be cast aside as redundant upon HRA's entry into force.

The second strand that emerges from the resurgence jurisprudence relates to the notion of commonlaw primacy, according to which the Convention plays second fiddle to the common law. This notion carries two implications. One is essentially pragmatic in nature, and is reflected in Lord Toulson's observation in Kennedy that, since the activation of the HRA, there has been a 'baleful and unnecessary tendency to overlook the common law'. ${ }^{31}$ Not only, on this view, should the common law not be passed over: it, rather than the Convention, should form the focal point when human-rights arguments are made. As Lord Mance said, also in Kennedy, '[T] he natural starting point in any dispute is to start with domestic law, and it is certainly not to focus exclusively on the Convention rights, without surveying the wider common law scene. ${ }^{32}$ The other aspect of common-law primacy goes deeper. It holds that it is not merely fitting on a pragmatic level that the common law should be prioritized when claims are framed, but also, and more fundamentally, that common-law rights form nothing less than the normative anchor-point in this area. As Lord Reed put it in Osborn, 'Human rights continue to be protected by our domestic law, interpreted and developed in accordance with the Act when appropriate. ${ }^{33}$ According to this view, common-law rights are no mere sideshow that, at best, gloss the Convention: to the contrary, it is the Convention that augments the common law. It must, however, be acknowledged that if this is the nature and direction of the relationship between the common law and the Convention, its outworking has, so far, taken place largely beneath the radar.

The third strand that can be identified within the resurgence jurisprudence concerns common-law dynamism. At its most modest, this notion implies that since the HRA's inception the common law has continued not only to exist, but also to evolve. That the common law is in general terms a dynamic institution is hardly a revelatory insight. Nevertheless, the Supreme Court's affirmation that the common law has continued and will continue to evolve in this particular area, the HRA notwithstanding, is significant - not least because it dispels any suggestion to the effect that the common law was frozen upon the entry into force of the Act. As Toulson $L$ said in $R$ (Guardian News and Media Ltd) $v$ City of Westminster Magistrates' Court, 'The development of the common law did not come to an end on the passing of the Human Rights Act 1998. ${ }^{34}$ In Kennedy, Lord Toulson - as he had by then become - reiterated this point by saying that 'it was not the purpose of the Human Rights Act that the common law should become an ossuary'. ${ }^{35}$

However, the notion of common-law dynamism extends beyond the negative proposition that the HRA has not precluded the common law's development: it also incorporates the positive proposition

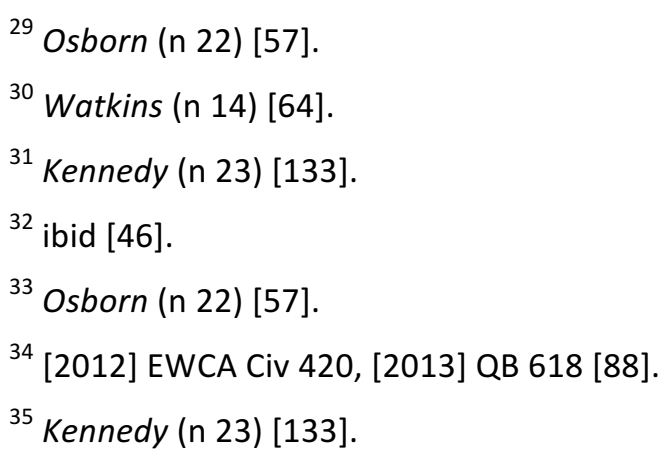


that such development has been informed and stimulated by the HRA. As Lord Reed said in Osborn, domestic human-rights law falls to be developed 'in accordance with' the HRA when this is appropriate. ${ }^{36}$ This raises a question about the nature and extent of the influence of the HRA upon the common law. At one extreme, it might be thought to imply that the common law has absorbed - or is ineluctably absorbing - all that the Convention has to offer, such that the common law has - or will - come to embody the Convention rights in their entirety. ${ }^{37} \mathrm{An}$ attraction (from one perspective) of this view is that repeal of the HRA or withdrawal from the ECHR would have little or no effect. If it were the case that the common law had ingested all that the HRA-ECHR regime had to offer, then casting that regime to one side would amount to nothing more than dispensing with an empty husk - a prospect about which those who wish to preserve domestic courts' capacity to uphold fundamental rights could be entirely sanguine.

Such an analysis is, however, hard to sustain. For one thing, it is clear that the bodies of common-law and Convention rights are not at present perfectly aligned: recently, for instance, the Supreme Court exhibited little sympathy for the suggestion that there might be a common-law right to vote analogous to that which is found in the Convention. ${ }^{38}$ For another thing, assigning such radical implications to the notion that the common law is being impacted by the HRA is inconsistent with both the gently evolutive nature of the common law and with such clear evidence as there is as to its interaction with Convention rights. When we consider those areas of law in which such interaction is discernible privacy being the most obvious example - we certainly find pre-existing common-law doctrine developing in the light of Convention rights and values. ${ }^{39}$ But what we do not find is evidence of an across-the-board, overnight reimagining of the common law. It seems likely, therefore, that whatever it is that has been going on, what has not taken place is the wholesale assimilation of Convention rights into the common law such that the latter has become nothing more - but nothing less - than an imprint of the former.

\section{Some Conclusions}

That Convention and common-law rights are neither perfectly aligned nor entirely distinct is relatively clear. The more-difficult question concerns the extent of such alignment as exists. By way of conclusion to this section of the article and introduction to its remainder, no answer to that question will be attempted, but two factors that make it either difficult to answer or misconceived will be offered.

First, perhaps paradoxically, the normative reach of common-law rights is an ultimately empirical question. Given the dynamic nature of the common law generally, and the acknowledged dynamism of common-law rights in particular, there is no a priori reason why the body of such rights should not

\footnotetext{
${ }^{36}$ Osborn (n 22) [57].

37 This argument turns to an extent on whether the reception of Convention rights in the UK can be characterized in terms of internationalisation as distinct from mere compliance, on which see Veronika Fikfak, 'English Courts and the "Internalisation" of the European Convention of Human Rights? - Between Theory and Practice' (2015) 4 Cambridge Journal of International and Comparative Law (forthcoming).

${ }^{38}$ Moohan v Lord Advocate [2014] UKSC 67, [2015] 2 WLR 141.

${ }^{39}$ Eg Campbell v MGN Ltd [2004] UKHL 22, [2004] 2 AC 457.
} 
develop in a way that over time yields a degree - perhaps a very high degree - of convergence with the Convention. However, determining the present degree of convergence is rendered difficult indeed, impossible - by virtue of the necessarily obfuscatory effect of the HRA itself. For reasons already explored, Convention rights have tended - at least until very recently - to occupy the centrestage. This has served to obscure the extent to which cognate common-law rights might exist and, if they do, how extensive they might be and how they might compare with their Convention counterparts. If the trend evidenced by recent Supreme Court judgments were to continue, such that greater attention were paid to the common law, and a merely supporting role assigned to the Convention, the terrain of the common law would in time become more-clearly defined. For now, however, the degree to which the body of common-law constitutional rights exceeds its pre-HRA self inevitably remains veiled, at least to some extent, in obscurity.

Second, the extent of alignment between common-law and Convention rights is rendered uncertain because - thus conceived - it addresses the question of the common law's normative reach in isolation. Such an approach is, however, deficient, since the question of normative reach can only meaningfully be considered in conjunction with the other vectors of human-rights adjudication namely protective rigour and constitutional resilience - identified above. Compare, for instance, the sharply contrasting views of Trevor Allan and Conor Gearty. Allan places great emphasis on the normative reach of the common law. He says that '[i]f ... the [HRA] has truly changed the British constitution, it is largely because it was planted in fertile soil', and that 'if it represents a true reconciliation between ideals of legality and democracy, it is surely one that the common law had, to a substantial degree, already provided for'.$^{40}$ Allan's view diminishes - almost to vanishing point the normative impact of the Act, characterizing it as little more than a statutory crystallization of that which was already to be found within the common law's interstices. Gearty, in contrast, excoriates the notion of the 'civil libertarian common law' as a 'fantasy' that overlooks what he dubs 'the partisanship of the common law for property and contract rights' and its service 'as a base for serial abuses of rights'. ${ }^{41}$

Although they appear to be implacably inconsistent, closer analysis suggests a possible reconciliation that acknowledges the pertinence of both views. Allan is surely correct that the common law betrays wide and deep traces of normative sympathy for values that underpin some - perhaps many Convention rights. But Gearty is surely right to point out that this has not always delivered tangible protection of relevant rights. Whether - and, if so, to what extent - values acknowledged at common law can be regarded as rights properly so called turns upon the rigour with which courts are able to protect them and the resulting the degree of constitutional resilience that they exhibit in the face of legislative or administrative infraction. It follows that if we are to characterize and understand the present reality and future potential of the common law, its normative reach must be examined in the light of distinct, yet cognate, questions about its protective commitment and, ultimately, the resilience with which it is capable of investing those norms that it acknowledges. However, as will be shown in the following sections, this analysis does not yield neatly uniform answers. Rather, the proximity of a

\footnotetext{
${ }^{40}$ Trevor Allan, 'Parliament's Will and the Justice of the Common Law: The Human Rights Act in Constitutional Perspective' (2006) 59 CLP 27, 31.

${ }^{41}$ Conor Gearty, 'On Fantasy Island: British politics, English judges and the European Convention on Human Rights' [2015] EHRLR 1, 2-3.
} 
given value to the common law's normative core influences the answers to those cognate questions, thus producing a complex picture that defies any bald exercise in characterisation that seeks to advance an undifferentiated account of how common-law rights work.

\section{Protective rigour}

Of what, then, is the common law capable when it comes to the protection of such norms as it recognizes? Since the concern of this article is, at least in part, to benchmark the potential of the common law against the HRA-ECHR regime, it is worth undertaking a side-by-side comparison of the protective approaches that they respectively adopt. This analysis will be undertaken by means of arguing that the common-law approach - encapsulated in the so-called principle of legality ${ }^{42}-$ discloses three particular, closely related strands, each of which maps clearly - albeit not perfectly - onto equivalent aspects of the protective machinery found in the HRA-ECHR. The three pertinent strands are conceptual reliance upon ultra vires reasoning; recourse to statutory construction as a primary vehicle for protection; and the provision of meaningful justificatory scrutiny.

\section{Ultra Vires}

The principle of legality is centrally concerned with the question whether the defendant has acted within or beyond its statutory authority. As Steyn LJ put it in Leech - advancing an analysis that Lord Reed recently endorsed in Pham ${ }^{43}$ - in cases of this type '[i]t is important not to lose sight of the precise nature of the question to be answered': '[t]he question is simply one of vires'. ${ }^{44}$ Thus, for example, the question in Leech itself was whether a prison rule according powers to censor prisoners' correspondence was authorized by the provision in primary legislation under which the rule had purportedly been made. The answer to that question turned - as we will see below - on the construction of the relevant statutory provision; for present purposes, the key point is that the lawfulness of the impugned secondary legislation was conceptually mediated through the doctrine of ultra vires.

The conceptual operation of the principle of legality is echoed by the way in which Convention rights can be conceptualised under the HRA as interpretive constraints upon statutory authority. Section 6(1) imposes an obligation on public authorities to act compatibly with Convention rights. However, $s$ $6(1)$ is qualified by $s 6(2)$, which relieves public authorities of the obligation to comply with the Convention to the extent that inconsistent conduct is licensed by primary legislation. Whether such conduct is statutorily licensed turns upon the construction of the relevant statutory provision, which, s 3(1) provides, must be interpreted compatibly with Convention rights - and hence as not licensing infractions of them - unless such construction is impossible. It follows that whether impugned administrative or legislative action is permissible under the HRA scheme turns ultimately upon whether relevant primary legislation authorises infringement of the right concerned. As a result, as David Feldman has written, the HRA can be understood to have extended the doctrine of substantive

\footnotetext{
${ }^{42}$ Michael Fordham and Thomas de la Mare, 'Anxious Scrutiny, the Principle of Legality and the Human Rights Act' [2000] JR 40.

${ }^{43}$ Pham v Secretary of State for the Home Department [2015] UKSC 19 [118].

${ }^{44}$ Leech (n 5) 208.
} 
ultra vires by 'turning incompatibility with Convention rights ... into a jurisdictional error of law' unless incompatible conduct is licensed by the relevant primary legislation..$^{45}$ The HRA thus does not break new conceptual ground when it comes to the protection of rights: it merely utilises and extends the vires-based technique that was already established at common law.

\section{Statutory Interpretation}

The second strand within the principle of legality concerns the interpretive approach by reference to which the dividing line between intra and ultra vires official action is drawn. It is evident that the common-law doctrine of legality employs techniques of construction comparable to, if not the same as, those that have been developed by the courts pursuant to the interpretive duty under $\mathrm{s} 3$ of the HRA. To some extent, the relevance of statutory interpretation is obvious from - is, indeed, the same point as - the fact that ultra vires forms a conceptual vehicle that is used for protecting both common-law and Convention rights. However, it is clear that in both contexts, the approach to statutory interpretation that is employed is anything but a literal one. So far as the HRA is concerned, as Lord Nicholls observed in Ghaidan, s 3 imposes upon the courts an interpretive duty 'of an unusual and far-reaching character' such that the intention manifested in the legislation being construed is rendered subservient to the intention manifested in s 3 itself. ${ }^{46}$ And importantly, whereas certain key pre-HRA cases, perhaps most notably Brind, had indicated that recourse to the Convention as an interpretive aid was appropriate only when the provision being construed was ambiguous, ${ }^{47}$ the interpretive obligation under $s$ of the HRA is subject to no such limitation.

The acknowledgment in pre-HRA jurisprudence of such an ambiguity trigger may be thought to point towards a key difference between the common-law and HRA interpretive models, the latter being substantially more potent given its applicability irrespective of ambiguity. However, the comparison is in fact a false one. It is true that when, prior to the HRA's inception, UK courts were invited to apply Convention rights qua Convention rights, concerns about back-door incorporation made them disinclined to do so in any direct way: absent ambiguity, Convention rights were not generally treated, pursuant to an interpretive approach, as vires constraints upon statutory authority. It is for this reason that notions such as 'anxious scrutiny' ${ }^{48}$ sometimes rang hollow: for courts to ask whether a defendant had acted Wednesbury unreasonably by adopting a measure that compromised a right is qualitatively different from asking whether a defendant has exceeded hard-legal limits upon its power that derive from the capacity of the right to act as a vires-based constraint.

Importantly, however, a different approach obtained - at least on some occasions - when courts were invited to decide cases on the basis of common-law, as distinct from Convention, rights. In such cases, recourse was made not to the anxious-scrutiny doctrine but to the principle of legality.

\footnotetext{
45 David Feldman, 'Convention Rights and Substantive Ultra Vires' in Christopher Forsyth (ed), Judicial Review and the Constitution (Hart 2000) 253.

${ }^{46}$ Ghaidan v Godin-Mendoza [2004] UKHL 30, [2004] 2 AC 557 [30].

${ }^{47}$ Brind (n 8) 747-8 (Lord Bridge), 760-2 (Lord Ackner).

${ }^{48}$ Bugdaycay v Secretary of State for the Home Department [1987] AC 514 (HL) 531 (Lord Bridge).
} 
Contrasting the decisions in Witham ${ }^{49}$ and $S m i t h^{50}$ is instructive in this regard. In the latter case, which concerned the legality of a policy prohibiting gays and lesbians from serving in the British armed forces, the right to respect for private life under Article 8 ECHR was clearly relevant. However, there was no question of that right operating as a hard constraint upon the relevant legal power. The most that the court was prepared to do was to determine whether, bearing in mind the human-rights context, the policy was unreasonable - which, the court concluded, it was not.

The reasoning in Witham - in which a common-law right was in play - was different. The question was whether subordinate legislation concerning court fees was invalid on account of its incompatibility with the constitutional right of access to courts. Holding that it was, Laws J observed that 'although the common law does not generally speak in the language of rights', the idea of common-law constitutional rights could - and does - consist in the proposition that they 'cannot be abrogated by the state save by specific provision in an Act of Parliament, or by regulations whose vires in main legislation specifically confers the power to abrogate'. ${ }^{51}$ In this way, it is the principle of legality - more specifically, the process of statutory construction - that breathes legal life into common-law values that would otherwise remain no more than that. ${ }^{52}$ Thus, to the extent that common-law rights can be said to be established through the principle of legality, they necessarily consist as the reciprocal counterpart to the legal incapacity which results from the strict construction of the relevant statute. Common-law doctrine and the HRA thus march hand-in-hand, in that both operate so as to deny administrative and (most) ${ }^{53}$ legislative actors any authority in the first place to infringe common-law and Convention rights respectively.

\section{Justificatory Scrutiny}

The third - and sometimes overlooked - strand within the principle of legality concerns justificatory scrutiny. This notion is clearly well-established under the HRA-ECHR scheme, proportionality review - which serves to distinguish legitimate state action from infractions of the Convention in relation to many of the non-absolute rights - being its epitome. A great deal has been written about whether, now that proportionality is an established feature of adjudication under the HRA, it should, perhaps through some process of cross-fertilization, be embraced as a universal vehicle for substantive review, so as to apply in both HRA or in 'regular' judicial-review cases. Powerfully though the case for such an approach has been put, ${ }^{54}$ it has not been made out. Proportionality makes little sense in cases that do not concern human rights or comparably valuable norms that are judged to warrant the form of justificatory scrutiny supplied by proportionality. ${ }^{55}$ Meanwhile, attempts to establish that

\footnotetext{
${ }^{49}$ Witham (n 4).

${ }^{50}$ Smith (n 9).

${ }^{51}$ Witham (n 4) 581.

${ }^{52}$ For a further, and more recent, example see Evans (n 26) (Lord Neuberger).

${ }^{53}$ The UK Parliament being the obvious exception.

${ }^{54}$ Paul Craig, 'Proportionality, Rationality, Review' [2010] NZ L Rev 265.

55 Tom Hickman, 'Problems for Proportionality' [2010] NZ L Rev 303; R (Rotherham Metropolitan Borough Council) v Secretary of State for Business, Innovation and Skills [2015] UKSC 6 [47] (Lord Sumption).
} 
administrative law has undergone some sort of 'righting' process ${ }^{56}$ - such that the whole enterprise, or at least the substantial majority of it, now concerns the protection of rights and is thus the proper preserve of proportionality review - are highly problematic. There is no convincing evidence to suggest that ordinary judicial-review principles have been overwhelmed by the notion of rights, and plenty of indications to the contrary; ${ }^{57}$ equally, although the jettisoning of Wednesbury reasonableness in favour of proportionality has been judicially contemplated, ${ }^{58}$ the courts have conspicuously declined to take that step.

Rejection of the view that proportionality should be embraced as a panacea might be thought to imply that it should instead be conceptualized as an exotic concept whose role is limited to cases involving Convention rights and whose presence within municipal law is parasitic upon the HRA. It might, in turn, be suggested that the repeal of the HRA would terminate domestic courts' flirtation with proportionality, leading to a return to the orthodoxy of Wednesbury. However, this does not necessarily follow. For one thing, concerns that appeared to inhibit the adoption of proportionality in pre-HRA cases have, at least to some extent, faded away in the light of experience gained during the currency of the Act. The almost-histrionic analyses of proportionality advanced by Lords Lowry and Ackner in Brind, for instance, were premised upon the notion that its deployment would wreak constitutional havoc by obliterating the hallowed distinction between 'appeal' and 'review'. ${ }^{59}$ Yet such predictions have proven wide of the mark. Even if - to bastardize the title of Jeffrey Jowell and Anthony Lester's pioneering article ${ }^{60}$ - proportionality was considered 25 or so years ago to be both novel and dangerous, it can be, and is, viewed with greater equanimity today. On this view, the courts' experience of proportionality review under the HRA has served to normalize and demythologize it in a way that sits uncomfortably with its characterisation as a European import that would depart the United Kingdom's shores in the course of a process of de-Europeanisation.

However, a more fundamental point remains to be made, which is that there is clear evidence showing that in common-law rights cases the proportionality method - if not the label and the finer points of the structure of the test - was in fact adopted prior to the HRA's activation. In other words, for all that concern might have been expressed about the constitutional dangers of proportionality review in cases like Brind ${ }^{61}$ the courts were actually engaging in it, albeit without explicitly acknowledging as much, prior to and independently of the HRA. This, in turn, suggests that proportionality - or at least

56 Thomas Poole, The Reformation of English Administrative Law' (2009) 68 CLJ 142; Michael Taggart, 'Reinventing Administrative Law' in Nicholas Bamforth and Peter Leyland (eds), Public Law in a MultiLayered Constitution (Hart 2003) (cf Michael Taggart, 'Proportionality, Deference, Wednesbury' [2008] NZ L Rev 423.

57 Jason Varuhas, 'The Reformation of English Administrative Law? 'Rights', Rhetoric and Reality' (2013) 72 CLJ 369.

${ }^{58} R$ (Association of British Civilian Internees (Far East Region)) v Secretary of State for Defence [2003] EWCA Civ 473, [2003] QB 1397.

${ }^{59}$ Brind (n 8).

60 Jeffrey Jowell and Anthony Lester, 'Proportionality: Neither Novel Nor Dangerous' in Jeffrey Jowell and Dawn Oliver (eds), New Directions in Judicial Review (Stevens 1988).

${ }^{61}$ Brind (n 8). 
key aspects of it - is not so much an innovation that would be capable of surviving the excision of relevant European influences, but an approach that has pre-European roots in domestic law.

The reasoning in Leech $^{62}$ - decided prior to the HRA's enactment and without to any EU-law doctrine of proportionality - is instructive in this regard. Having concluded that, as noted above, the question was one of vires, Steyn LJ went on to construe the statute in order to determine to what extent, if any, it should be taken to authorize the making of rules that were incompatible with the common-law right of access to court. It is the nature of the interpretation at which Steyn $L J$ arrived which is significant for present purposes. In particular, he did not conclude that the statute straightforwardly ruled out any administrative rules having any degree of impact upon the relevant right. Rather, he construed the statute as conferring upon the relevant constitutional actor only such authority to interfere with the right as could be justified by reference to an 'objective need' ${ }^{63}$ The statute was thus to be taken to have licensed conduct incompatible with the right only to the extent that official control over correspondence between prisoners and solicitors was 'in the interests of the regulations of prisons' ${ }^{64}$ this, said Steyn $\mathrm{LJ}$, demanded the existence of a 'self-evident and pressing need'. ${ }^{65}$ This is a graphic illustration of the potential of the principle of legality. While, no doubt for presentational reasons, there was no suggestion that a free-standing proportionality test was being applied, such a test was in effect internalized within the process of statutory construction. Secondary legislation interfering with access to the court to an extent greater than could be objectively justified by reference to a pressing need would be unlawful because it would be ultra vires, given that the enabling statute had been held to confer only the authority to interfere with access to courts to a justifiable extent.

Leech is not an isolated example of proportionality being applied at common law. Indeed, what was implicit in Leech was explicit in Daly. ${ }^{66}$ Although often interpreted as a very early authoritative illustration of the courts' willingness to engage in proportionality review under the HRA, Daly was in fact, as noted above, decided at common law. As such, the explicit use made of proportionality in Daly falls properly to be understood as an endorsement of its capacity to operate in common-law rights, as opposed to Convention rights, cases. Nor is domestic courts' embrace of proportionality limited to the common-law rights context. It is deployed with increasing explicitness in (some) substantivelegitimate-expectation cases, ${ }^{67}$ while the Supreme Court has recently given arguably its clearest indication yet that proportionality can apply in cases lacking any European dimension and concerning a fundamental status as distinct from a human or constitutional right. ${ }^{68}$ It is unnecessary for the purpose of this argument to finesse away the fact that in cases concerning common-law values courts

${ }^{62}$ Leech (n 5).

${ }^{63}$ Leech (n 5) 212.

${ }^{64}$ ibid.

${ }^{65}$ ibid. Lord Steyn returned to the notion of 'pressing social need' in $R v$ Secretary of State for the Home Department, ex parte Simms [2000] 2 AC 115 (HL) 129.

${ }^{66}$ Daly (n 18).

${ }^{67}$ Eg $R$ v North and East Devon Health Authority, ex parte Coughlan [2001] QB 213 (CA); R (Nadarajah) v Secretary of State for the Home Department [2005] EWCA Civ 1363; Paponette v Attorney General of Trinidad and Tobago [2010] UKPC 32, [2012] 1 AC 1.

${ }^{68}$ Pham (n 43). 
do not uniformly have recourse to proportionality. ${ }^{69}$ The point, rather, is that there is a clear basis in the case law for the proposition that proportionality is something that can and does legitimately operate as a common-law review tool, such that, as Sedley $L$ put it in Quila, it has 'a life of its own' in domestic public law.

\section{The Human Rights Act, the Common Law and the Judicial Function}

The foregoing analysis suggests that if the HRA were to be repealed - and even if the ECHR were withdrawn from - the conceptual and doctrinal scaffolding needed for a recognizable regime of human-rights protection would not thereby be dismantled. Having said all of this, however, it would be counterfactual to suggest that the HRA has made no difference. At the very least, the Act has had a significant emboldening effect. It has, for instance, caused the proportionality test to emerge from the shadows. ${ }^{71}$ The Act has been invoked to justify sometimes-unfamiliar levels of judicial interventionism - as it was by Lord Bingham in Belmarsh, citing the 'wholly democratic mandate' that it bequeaths to the courts. ${ }^{72}$ And the sort of radical interpretive surgery performed in cases like Ghaidan is evidently aided by the courts' ability fall back on the argument that far from playing fast and loose with parliamentary intention, they are simply fulfilling the intention manifested in $\mathrm{s} 3(1)$ of the HRA. ${ }^{73}$

The reasons for greater judicial boldness under the HRA are not hard to fathom: the legislation furnishes the courts with a ready-made defence to charges of unwarranted judicial activism, enabling them to plead the implementation of Parliament's sovereign will when accused of overstepping the mark. In contrast, common-law rights and their enforcement by courts are necessarily the product of something other than parliamentary intention. As such, they cannot benefit from the protective, democratic cloak afforded to the Convention rights by the HRA. While this might be thought to signify that common-law rights are destined to remain the constitutional inferior of their Convention counterparts, it would be rash to hasten to such a conclusion. Such a line of argument presupposes that the Act has served to permit courts to do that which would otherwise be improper; that the constitutional licence bestowed by the Act might just as easily be revoked by means of its repeal; and that the permissive effects of the Act - being legally countercultural - are strictly confined to those matters falling within its legislative parameters. This analysis places great emphasis upon the HRA as an agent of (limited) legal change, characterising it as something that sits atop regular domestic law whilst leaving the underlying architecture of the constitution fundamentally unchanged. It is, however, worth exploring an alternative narrative, which holds that the Act has served to shine a light

\footnotetext{
${ }^{69}$ For discussion of ongoing recourse to reasonableness by senior courts, see Jason Varuhas, 'Against Unification' in Hanna Wilberg and Mark Elliott (eds), The Scope and Intensity of Substantive Review: Traversing Taggart's Rainbow (Hart 2015) 109-14.

${ }^{70} R$ (Quila) v Secretary of State for the Home Department [2010] EWCA Civ 1482, [2011] HRLR 11 [36].

${ }^{71}$ Daly (n 18).

${ }^{72}$ A v Secretary of State for the Home Department [2004] UKHL 56, [2005] 2 AC 68 [42].

${ }^{73}$ Ghaidan (n 46).
} 
upon latent - but to an extent unrealized - potential within the common law, and that the genie, now that it is out of the bottle, may return only reluctantly, if at all. ${ }^{74}$

A useful vehicle for exploring these two contrasting narratives is supplied by the sharp disagreement between Lords Sumption and Kerr in the case of Carlile. ${ }^{75}$ The case concerned the Home Secretary's refusal to allow an individual to enter the UK in order to address parliamentarians, the conduct of diplomatic relations and attendant national security concerns being cited in support of the decision. The judgment reveals a broad range of judicial opinion about the proper role of the court in such a case. At one end of the spectrum sits Lord Sumption. Although eschewing the language of 'deference', ${ }^{76}$ Lord Sumption adopted an approach that was strikingly abstemious. Indeed, he went so far as to suggest that, in the circumstances of the case, the courts' institutional and constitutional circumstances dictated not merely that weight be ascribed to the executive's view, but that key aspects of the proportionality test - namely necessity and fair balance - should be abandoned entirely in favour of a bare rationality assessment. ${ }^{77}$ In contrast, Lord Kerr - dissenting - said that the courts must undertake 'fearless, independent review of the justification for interference with Convention rights' ${ }^{78}$ and that, ultimately, '[w]e do not ask whether the Secretary of State's view is tenable; we ask whether it is right'. ${ }^{79}$

On one level, this disagreement appears to concern the effects of the HRA. Lord Sumption, for instance, said that while the Act may to some extent have modified pre-existing constitutional arrangements, it 'did not abrogate the constitutional distribution of powers between the organs of the state'.$^{80}$ In contrast, Lord Kerr's understanding of the constitutional implications of the HRA is more radical: he considers courts to have been charged by Parliament with the 'solemn duty' to examine not only 'the reasons given for the interference [with the right] but also to decide for themselves whether that interference is justified' ${ }^{81}$

However, on reflection, the site of this disagreement must lie at a more fundamental level. Any debate about whether the HRA permits this or that degree of activism - whether by way of incursions into formerly 'forbidden areas', 82 radical interpretation or more-intensive scrutiny - is a largely arid one. The Act does not tell us what should and should not be regarded as justiciable; it does not tell us what

\footnotetext{
${ }^{74}$ This is not to suggest that in developing the doctrine of common-law constitutional rights courts are merely discovering rights that were always present. Rather, the point is that the common law, as an institution, may have a capacity to accommodate rights-protection that has hitherto remained somewhat unexploited.

${ }^{75} R$ (Carlile) v Secretary of State for the Home Department [2014] UKSC 60, [2014] 3 WLR 1404.

${ }^{76}$ ibid [22].

77 ibid [32].

${ }^{78}$ ibid [176].

${ }^{79}$ ibid [158].

${ }^{80}$ ibid [28].

${ }^{81}$ ibid [152] (emphasis in original).

${ }^{82}$ The term used by Lord Phillips MR in $R$ (Abbasi) $v$ Secretary of State for Foreign and Commonwealth Affairs [2002] EWCA Civ 1598, [2003] UKHRR 76.
} 
the word 'possible' in s 3(1) means; and it has nothing to say about the intensity of review save that it implicitly requires courts to have recourse to proportionality - itself a catholic notion - to the extent that that concept inheres in certain Convention rights. That the text of the Act is not dispositive of such matters is demonstrated by the very existence of disagreements such as that which arose in Carlile.

What really underpins the difference between Lords Sumption and Kerr is a disagreement about the nature of the judicial role itself. Lord Sumption has made his views on this matter crystal clear, both in his judgments and in notable extra-curial contributions, including his F A Mann Lecture. ${ }^{83}$ Although Lord Sumption is susceptible to the charge that he attacks a straw man by in the first place mischaracterising the degree to which judges actually intervene in the 'political' realm, ${ }^{84}$ it is clear enough that he views the judicial role in highly limited terms. It is unsurprising, therefore, that he ascribes a conservative interpretation both to the constitutional implications of the HRA and to the pre-existing constitutional arrangements upon which it operates - the upshot being that, for Lord Sumption, a previously limited judicial role ought not to be understood as having been radically extended by the Act.

Lord Kerr, it is plain, adopts a very different starting point - one that influences both his reading of the Act and of the underlying constitutional architecture. While he does not downplay the relevance of the HRA - he acknowledges that it is the Act that requires courts to determine the legality of government action that is alleged to infringe Convention rights - he insists that what courts do under the HRA captures something that is inherent within their role:

Whether executive action transgresses a Convention right ... and, if it does, the importance to be attached to the right interfered with are emphatically matters on which courts are constitutionally suited to make judgments.

Meanwhile, although Lord Neuberger adopted an intermediate position in Carlile, he has, speaking extra-judicially, said that the powers exercised by the courts under the HRA 'are necessary if the rule of law is to prevail'. ${ }^{85}$ This implies that, in line with Lord Kerr, Lord Neuberger takes the view that what the courts do under the HRA is underpinned by constitutional foundations that go far deeper than the Act itself. This perception is reinforced by the judgment given by Lord Neuberger - with which Lords Kerr and Reed agreed - in Evans, in which the role of the judiciary was portrayed as a function of rule-of-law values that are constitutionally innate. ${ }^{86}$

\footnotetext{
${ }^{83}$ Jonathan Sumption, 'Judicial and Political Decision-Making: The Uncertain Boundary' (F A Mann Lecture, 9 November 2011) <http://www.documentcloud.org/documents/265505-jonathan-sumption-mannlecture.html> accessed 25 March 2015. See also Lord Sumption, 'The Limits of Law' (Sultan Azlan Shah Lecture, 20 November 2013) <https://www.supremecourt.uk/docs/speech-131120.pdf> accessed 25 March 2015.

${ }^{84}$ This is one of many criticisms of Sumption's Mann lecture made by Sir Stephen Sedley, 'Judicial Politics' (2012) 34 London Review of Books 15.

${ }^{85}$ Neuberger (n 28).

${ }^{86}$ Evans (n 26) [51]-[59].
} 
It follows that if we wish to appreciate the constitutional implications of the HRA - whether the implications of its enactment or the potential implications of its repeal - we must look beyond it. The reception and application of the HRA have not been dry matters of textual analysis. They turn at least as much - and probably far more - on prior and underlying conceptions of the judicial function and of the proper relationship between the courts and the political branches. There will always be scope for disagreement about the answers to such questions. That is so under the present constitutional dispensation, and it would be equally so if the notion of common-law rights - in the absence of the Act or the Convention - were to go it alone. However, the pre-HRA forms of protection available at common law - together with the deepening, outside the rights context, of prevailing conceptions of the courts' constitutional role in the decades preceding the HRA's enactment - lend at least some credence to the positions adopted by Lords Kerr and Neuberger. At the very least, the correspondence identified above in relation to the protective tools deployed at common law and under the HRA-ECHR regime suggests that what the courts do pursuant to the latter involves, at least to some extent, the performance and development of pre-existing and innate, as opposed to wholly novel and imposed, judicial functions. This is not to suggest that the HRA is no more than a decoration. Its impact has been real, and its repeal would not be inconsequential. But it would be naïve to suppose that the HRA has bestowed, and that its repeal would revoke, a set of judicial functions that are otherwise constitutionally alien. The HRA has regularized a relatively bold approach to human-rights adjudication, and has provided a convenient response to charges of judicial overreach; and without the democratic shield afforded them by the Act, the courts would undoubtedly be more exposed. But the convenience of the shield does not imply its indispensability.

\section{Constitutional resilience}

In the absence of the HRA, then, the common law would continue to supply a basis for judicial enforcement of whatever rights are recognized at common law, by reference to techniques including the ultra vires concept, statutory interpretation and the imposition upon public authorities of a justificatory burden - that bear some resemblance to the contents of the courts' HRA toolkit. However, even if this analysis is accepted, a further question - concerning constitutional resilience - remains.

Viewed from one perspective, common-law and Convention rights are broadly similar in terms of their constitutional resilience. Both must yield in the face of implacably inconsistent primary legislation, meaning that the sovereignty of Parliament circumscribes the resilience of both forms of rights. However, this analysis, although accurate as far as it goes, does not go far enough. This argument will be developed in two stages. First, it will be shown that the resilience of Convention rights under the HRA is substantially greater than the foregoing analysis implies. Second, although the position at common law is quite different, an analogical argument will be developed to the effect that commonlaw rights may nevertheless enjoy a greater degree of constitutional security than an orthodox analysis would suggest.

\section{Convention Rights and Common-Law Rights Compared}

When a remedy is granted by a UK court in respect of Convention rights, the legal effect is necessarily limited. In the case of a declaration of incompatibility under s 4 of the HRA, the legal effect is nonexistent save that the power to make a 'fast-track' amendment is thereby triggered. If, on the other 
hand, an interpretive remedy is issued by means of a construction rendered under $\mathrm{s} 3$, although the burden of inertia is allocated differently, the remedy is ultimately reversible in that it is open to Parliament as a matter of domestic law to re-enact the relevant provision in terms clear enough to defy consistent construction. However, this analysis overlooks the crucial fact that the constitutional resilience of Convention rights defies calibration in exclusively domestic-law terms, the internationallaw purchase of such rights generally investing adjudication under the HRA with a degree of legal bite that adjudication at common law appears to lack.

Such bite flows from the fact the UK is subject to binding international obligations to secure to everyone within its jurisdiction the rights set out in the Convention ${ }^{87}$ and to abide by judgments issued by the Strasbourg Court. ${ }^{88}$ Of course, although it is likely, it is not inevitable that official defiance in the face of a domestic judgment would trigger an application to that Court; and it is not inevitable that, if such an application were to be made, the ECtHR would reach the same conclusion as the domestic court. These two possibilities are different in type. The former turns not upon the extent of the UK's obligations under the Convention, but upon practical happenstance such as the inclination and financial capacity of the party to take the case further. The latter possibility, in contrast, reflects the extent of the UK's international obligations, acknowledging, for instance, the chance that the Strasbourg Court might interpret the Convention differently or hold that the impugned national legislation to fall within the margin of appreciation. Indeed, it is even possible for a domestic court to rule that a given statutory provision should be considered to breach the Convention right when the matter is viewed from a domestic perspective, while simultaneously acknowledging that the measure might survive scrutiny in Strasbourg on account of the likelihood of that Court extending a margin of appreciation broader than the corresponding margin afforded at the domestic level by means of the doctrine of deference. The Nicklinson case highlights precisely this possibility. ${ }^{89}$ But while, for these reasons, domestic relief under the HRA does not inevitably mean that the UK is (viewed from Strasbourg's perspective) in breach of its obligations under the Convention or that binding Strasbourg adjudication will ensue, it generally means those things. And it follows that to postulate that the UK Parliament is free - by dint of the doctrine of legislative supremacy - to ignore $s 4$ declarations and reverse $s$ interpretations implies an unduly blinkered view.

This is not to suggest that Convention rights can straightforwardly be regarded as limits upon Parliament's authority (and, hence, as an impediment to parliamentary sovereignty). The position is more complex than this, because the parliamentary sovereignty and the Convention rights exist, respectively, upon domestic and international legal planes that, even if not wholly unrelated, are ultimately distinct. Indeed, it is in this analysis that the subtlety of the HRA regime resides. When, for instance, a declaration of incompatibility is issued, the domestic court is effectively signalling that the legislation in question, although valid as a matter of national law, is unlawful judged against the benchmark of the ECHR which is binding upon the UK in international law. ${ }^{90}$ And while this does not call into question the sovereignty of Parliament, it does indicate that Parliament's legislative action

${ }^{87}$ ECHR, art 1

${ }^{88}$ ECHR, art 46(1).

${ }^{89} R$ (Nicklinson) v Ministry of Justice [2014] UKSC 38, [2014] 3 WLR 200.

${ }^{90} \mathrm{~A}$ similar point can be made in relation to a $\mathrm{s} 3$ interpretation, the implication of which is that unless Parliament is prepared to accept the interpreted rendered by the court, UK law will be incompatible. 
has consequences that sound in another - international - sphere. This does not remove the distinction between the two spheres, but it does erode it. In particular, it permits obligations that are binding as a matter of international law to occupy a place on the domestic constitutional stage, and thus to steal some of the limelight from the doctrine of parliamentary sovereignty. This is different from saying that the doctrine is undermined: the point, rather, is that the adoption of a wider perspective is forced, thus placing in sharp relief the inevitable parochialism of what is necessarily a domestic-legal construct. In this way, the perennial conundrum - who has the last word? - that arises whenever fundamental rights and legislative authority are juxtaposed, far from being resolved by the HRA, is sidestepped. This is facilitated by, in effect, outsourcing to the Convention machinery the ultimate task of safeguarding rights. That machinery serves, in one sense, as a final-resort guarantee of rights - yet one that does not directly cut across the domestic sovereignty principle.

It is against this background that the characterisation of HRA remedies as 'dialogic' falls to be considered. ${ }^{91}$ On the face of it, the Act - by withholding from the courts any form of strike-down power - is quintessentially dialogic. Yet such domestic remedies acquire a schizophrenic character because they are parasitic upon rights that bite in international law and which may attract binding Strasbourg adjudication. For this reason, the HRA is significantly inconsistent with the 'new Commonwealth model of constitutionalism' developed by Stephen Gardbaum, two key aspects of which are 'weak-form judicial review' and the assignment to the legislative branch of the 'final word' ${ }^{92}$ While it is possible to ascribe such characteristics to the HRA regime when it is viewed through an exclusively domestic lens, the same is clearly not true when an international-law lens is applied. ${ }^{93}$

This analysis suggests a fundamental distinction not only between the HRA-ECHR regime and Gardbaum's model, but a further, and equally stark, distinction between that regime and the doctrine of common-law constitutional rights. Under the HRA, the possibility of reversal - by means of Parliament either ignoring a declaration of incompatibility or replacing a compatibly interpreted provision with one that defies a construction consistent with the relevant right - is slight, being heavily qualified by the ultimately binding nature of the ECHR. In contrast, the possibility of reversal at common law is - or at least appears to be - far greater. In this respect ${ }^{94}$ the system of commonlaw rights is closer to Gardbaum's model than is the HRA-ECHR regime, the 'final word' remaining more obviously with the legislature, and judicial review being more clearly 'weak-form' in nature. Judicial application of common-law rights is thus, it seems, more unambiguously dialogic - in the sense that judicial review is weak-form in nature - than is judicial application of Convention rights via the HRA. That this is so seems to flow naturally from the fact that common-law rights - unlike their Convention counterparts - occupy the same, domestic, constitutional space as the doctrine of parliamentary sovereignty. As such, that doctrine appears to form an absolute limit upon the constitutional resilience of common-law rights.

\footnotetext{
${ }^{91}$ See generally Tom Hickman, Public Law After the Human Rights Act (Hart 2010) ch 3.

92 Stephen Gardbaum, The New Commonwealth Model of Constitutionalism: Theory and Practice (CUP 2013) ch 2.

${ }^{93}$ Gardbaum acknowledges, but arguably underplays this significance of, this point. See eg ibid 195.

${ }^{94}$ But, admittedly, not in certain others.
} 


\section{Parliamentary Sovereignty and Constitutional Indeterminacy}

However, it is worth pausing to consider whether this orthodox account adequately captures the nature - and full subtlety - of the relationship between common-law rights and the legislative authority of Parliament. This question can best be explored by reflecting upon the principal vehicle namely, interpretation - that is available to courts seeking to uphold rights at common law. There is, of course, a well-explored normative dimension to this question. Trevor Allan, for instance, argues that interpretation is a device so potent, and the distinction between it and judicial invalidation ultimately so barren, as to foreclose the possibility of properly construed legislation impinging upon fundamental rights (or values).$^{95}$ However, my purpose here is not to engage in that normative debate, but to suggest that the factual possibility of judicial disobedience to statute, whether explicitly or under the cover of interpretation, is in itself a consideration that must be taken into account when attempting to understand how legislation and common-law rights and values relate to one another. This, it will be argued, highlights what can simultaneously be considered the potential and the limits of common-law rights viewed in terms of their constitutional resilience.

A useful starting-point is the oral evidence given by Lord Phillips to the House of Commons Select Committee on Political and Constitutional Reform. ${ }^{96}$ In the course of a discussion about the prospect of judicial strike-down of 'unconstitutional' legislation, Lord Phillips indicated that before such a possibility - which would precipitate a 'constitutional crisis' - were contemplated, the courts would first have resorted to interpretive tools, even if this amounted to ascribing to the relevant provision 'an interpretation it ... couldn't bear' ${ }^{97}$ Such a step, said Lord Phillips, would be justified by dint of being a constitutionally seemly way of the court seeking to throw 'the gauntlet back to Parliament' ${ }^{98}$ This, said Lord Phillips, would be tantamount to the Court saying to legislators: 'We have pulled you back from the brink. Are you really going to persist with this?' This, he said, 'is what the House of Lords did in Anisminic' ${ }^{99}$

Lord Phillips does not - at least in these remarks - commit himself to a normative position on the question of whether courts or Parliament ought to have the final word in situations of this type. Rather, his observation is empirical in nature, and amounts to a particular conception of interpretation as a remedial tool. Taken to its logical conclusion, Lord Phillips's analysis of interpretation results in its characterization as a soft-form of strike down power: one that facilitates judicial neutralization of constitutionally offensive legislative provisions, subject to the possibility of Parliament's taking up the gauntlet by re-enacting the provision in yet-starker terms. This raises some obvious questions. What happens if Parliament does take up the gauntlet? Are the courts obliged to roll over if it does? And, if so, does judicial review pursuant to common-law rights remains essentially weak-form in nature -

\footnotetext{
${ }^{95}$ Trevor Allan, The Sovereignty of Law: Freedom, Constitution and Common Law (OUP 2013) chs 4-5.

${ }^{96}$ Political and Constitutional Reform Committee, Constitutional Role of the Judiciary if there were a Written Constitution (HC 2013-14, 802) 16-17.

${ }^{97}$ ibid.

${ }^{98}$ ibid.

${ }^{99}$ ibid. The approach of Lords Kerr, Neuberger and Reed in Evans (n 26) is arguably a further - if less stark - example of such counter-textual interpretation, albeit that Evans was a case that was concerned not explicitly with constitutional rights but with constitutional principles.
} 
consistent, in this aspect, with Gardbaum's paradigm, ${ }^{100}$ and distinct from the stronger-form review available under the HRA?

In seeking to navigate these issues, two possible approaches arise. One involves seeking to supply a decisive answer to the question what would happen if the courts and Parliament were to find themselves locked in the sort of constitutional struggle envisaged by Lord Phillips. The difficulty with this approach is that it seeks to supply false certainty in relation to a matter that is inherently indeterminate, a considerable diversity of normative opinion being reflected in conflicting descriptive accounts of the constitutional status quo. It is true that some senior judges - including Justices of the Supreme Court - are today prone to expressing less-than-fulsome support for the notion of wholly unconstrained legislative authority in a way and with an explicitness that would have been surprising, even shocking, until relatively recently. ${ }^{101} \mathrm{~A}$ very recent example is supplied by Lord Hodge's judgment in Moohan, in which he was unwilling to exclude the possibility that if 'a parliamentary majority abusively sought to entrench its power by a curtailment of the franchise or similar device, the common law, informed by principles of democracy and the rule of law and international norms, would be able to declare such legislation unlawfull ${ }^{102}$ But this is a far-from-universal view among the senior judiciary, Lord Neuberger, for instance, having unambiguously said extra-judicially that it is clear that parliamentary sovereignty is absolute'. ${ }^{103}$

Attempting to resolve the tension between the empirical positions adopted by Lords Hodge and Neuberger is an ultimately futile endeavour at least at the present time, since the choice between them turns upon a chapter in the UK's constitutional story that is presently - and may permanently remain - unwritten. In the absence of a constitutional crisis of the type contemplated by Lord Phillips, the opportunity simply has not arisen for it to be determined whether legislative abrogation or judicial enforcement of a fundamental constitutional right or value would prevail in the event of explicit interinstitutional conflict. I have argued elsewhere that the inherent indeterminacy implied by this analysis can - and should - be perceived not as a constitutional deficiency but as a constitutional feature: one that promotes comity and serves to discourage both sides from trespassing beyond the brink. ${ }^{104}$ Rather than problematizing this inherent ambiguity in our constitutional order, we have no choice but to embrace it - and to seek to understand its implications for the institutional relationship between the judicial and political branches. Viewed in terms of the constitutional resilience of common-law rights, such indeterminacy cautions against ready judicial invocation of the putative nuclear option contemplated by Lord Hodge, as well as against legislative retaliation in the event of the sort of soft strike-down envisaged by Lord Phillips. The upshot is that such interpretive activism acquires a

\footnotetext{
${ }^{100}$ Gardbaum (n 92).

${ }^{101}$ Eg R (Jackson) v Attorney General [2005] UKHL 56, [2006] 1 AC 262 [102] (Lord Steyn), [104]-[107] (Lord Hope), [159] (Lady Hale); AXA General Insurance Ltd v HM Advocate [2011] UKSC 46, [2012] 1 AC 868 [50] (Lord Hope).

${ }^{102}$ Moohan v Lord Advocate [2014] UKSC 67, [2015] 2 WLR 141 [35].

${ }^{103}$ Lord Neuberger, 'Who are the masters now?' (Lord Alexander of Weedon Lecture, 6 April 2011).

104 Mark Elliott, 'The Principle of Parliamentary Sovereignty in Legal, Constitutional, and Political Perspective' in Jeffrey Jowell, Dawn Oliver and Colm O'Cinneide (eds), The Changing Constitution (8th edn, OUP 2015).
} 
constitutional edge, thanks to the veiled possibility of judicial retaliation in the event of legislative escalation.

The picture so far as common-law rights is concerned is thus complex, viewed in terms of its relationship with both Gardbaum's model and the HRA-ECHR regime. So far as the former is concerned, the extent to which judicial review pursuant to common-law rights can be characterized as weak-form, and the legislature considered to have the final word, becomes the subject of uncertainty. Equally, the supposition that common-law rights are more constitutionally fragile than HRA-ECHR rights becomes questionable, the sort of interpretive strategy identified by Lord Phillips implying a capacity on the part of the courts to send across Parliament's bows a warning shot at least as potent as that entailed by a declaration of incompatibility. Indeed, a form of symmetry emerges: neither an HRA declaration nor a radical common-law interpretation explicitly calls into question Parliament's sovereign capacity to have the final word, yet each hints at the constitutional difficulties likely to be precipitated should it seek to press its putative legal right to do so.

There are, however, dangers in seeking to take this analysis too far. The HRA has served to normalize the notion of judicial review of primary legislation: rendering an interpretation pursuant to $s$ of the HRA or issuing a declaration of incompatibility under $s 4$ are steps which, while relatively rare, are unexceptional. And every time a court takes such a step, the underwriting effect of the ECHR is triggered, such that - subject to the relatively slight possibility of the Strasbourg Court adopting a more-lenient approach - Parliament becomes unambiguously boxed in as a matter of international law. The position in relation to common-law rights is clearly different in two senses. First, there is nothing unambiguous about the potentially constraining effect of common-law review: its existence is, at best, putative. Second, even if the possibility were to exist, the indications are that courts relying upon common-law rights or values would risk precipitating a constitutional crisis - by assigning to a provision a meaning it could not textually bear and subsequently exhibiting disobedience in the face of legislative retaliation to such an interpretive adventure - only in extreme circumstances. This is evidenced by the fact that judicial speculation about the possibility of strike-down or non-application of primary legislation is almost invariably accompanied by the provision of lavishly extravagant examples such as a full-frontal assault upon the basic tenets of democracy ${ }^{105}$ or the evisceration of the courts' powers of judicial review. ${ }^{106}$

This suggests that in order for even the prospect of judicial disobedience to statute to arise, the right in question must be especially fundamental and the breach of it so egregious as to strike at its very heart. It follows that while common-law rights may - rarely - have the potential to exert the sort of constraining effect upon Parliament that that Convention rights have, that potential would likely only ever be realized in extremis. This takes us full circle, to the relationship between the three vectors of human-rights adjudication - concerning normative reach, protective rigour and constitutional resilience - identified at the beginning of this article. If a common-law right were ever to turn out to be an absolute brake upon legislative authority, the likelihood is that it would have to lie dead centre within the normative core of common-law rights. Only then - if ever - would be it possible to begin to contemplate the ascription to the right of a degree of resilience that would warrant its protection

\footnotetext{
${ }^{105}$ Eg Moohan (n 102).

${ }^{106}$ Eg Jackson (n 101).
} 
in the face of flatly, even explicitly, inconsistent legislation. This is to be contrasted with the position that obtains under the HRA which, in this respect, is an essentially monolithic one, the constraining force of the Convention machinery being implicated whenever a domestic court takes remedial action, whether by means of interpretation or declaration.

\section{Concluding Remarks}

What, then, is the relationship between common-law and HRA-ECHR rights, and to what extent might the former be a substitute for the latter? It would be naïve to suggest that common-law rights could seamlessly step in if the HRA were repealed or if the UK resiled from the Convention. The differences between the regimes are such that one cannot simply stand in for the other. The normative reach of the common law traditionally was - and probably still is - more modest than that of the Convention. The rigour of the protective techniques available under the Act has not always been imitated at common law. And Convention rights (at least for as long as the UK is a party to the treaty) have a degree of constitutional resilience that their common-law counterparts do not (at least straightforwardly and uniformly) enjoy. The courts' protective commitment to - and the resulting degree of constitutional resilience enjoyed by - rights lying at or near the common law's normative core may confer upon those rights a degree of legal security approximating to that which is associated with Convention rights under the HRA; but the same cannot plausibly claimed of the whole range of rights (and values) acknowledged at common law.

Nevertheless, it would be mistaken to suppose that domestic courts would be powerless to uphold fundamental rights if they were to be denied the instruments presently placed at their disposal by the Act. The common law's normative reach may well be more limited than the Convention's - but the common law is a dynamic institution that has not stood still these past 15 years. The Act explicitly equips courts with protective tools in a way that the common law does not. Yet the protective regime enshrined in the Act echoes, even if it does not simply reproduce, that which is found at common law, in terms of the conceptual basis of protection, reliance upon statutory construction and recourse to forms of justificatory scrutiny that amount to or take the form of proportionality review. And although common-law rights may not unambiguously possess the constitutional resilience enjoyed by Convention rights, it does not follow, for the reasons considered, that common-law rights should be taken to be universally fragile in the face of constitutionally inimical legislation.

This is not to suggest that the HRA has not made any difference; it clearly has. But a question remains about how we are to characterize the difference it has made. Three possibilities arise. The first depicts the Act as an exotic bird sitting atop and apart from the common law, leaving no perceptible imprint and ready to be spirited away at the stroke of a legislative pen. For reasons explored in this article, such a view is untenable: it misunderstands both the contextual background against which the HRA was enacted and the cross-fertilization of domestic law that has taken place under its influence.

A second possibility involves the portrayal of the Act as having effected enduring transformation of the common law. There is more mileage in this view. Succour is given to it by, for example, the phenomenon, discussed earlier, of the absorption of certain Convention rights into the common law, and the emboldening effect that the Act has had. However, this depiction of the Act's impact is also deficient - or at least incomplete. The language, and the notion, of transformation is ultimately inapposite because it depicts the common law and the Convention as polar opposites, the latter taking 
the form of an influence that, even if it has not proven transitory, was, to begin with, foreign and strange. The reality, however, is that to the extent that the Act has effected change, it has succeeded in doing so because in the common law it has found a willing partner.

This points to a third - and preferable - mode of characterisation. When we consider the degree of correspondence that exists between the common-law and HRA regimes, we find that the relationship is not a one-way street. In the HRA model we find aspects of norms, practices and approaches that were already to some degree evident at common law, albeit that they are perhaps reflected in the Act in a crisper, starker form. It would be going much too far to suggest that the HRA is a mirror that can be held up to the common law so as to reveal what it has really been all along. But there is nevertheless a grain of truth in that metaphor. If the common law has been invigorated by the Act, then that, at least in part, is because the Act has served to highlight the capacity of the common law. And it is this deepening of our appreciation of the nature and potential of the courts' inherent constitutional role that will be the enduring legacy of the Act, however long or short its remaining time on the statute book might be. 